\title{
Synthesis of some cyclooctane-based pyrazines and quinoxalines
}

\author{
Mostafa Honari Alamdari, ${ }^{\text {a,c }}$ Madeleine Helliwell, ${ }^{\mathrm{b}}$ Mehdi M. Baradarani, ${ }^{a}$ \\ and John A. Joule ${ }^{b_{*}}$ \\ ${ }^{a}$ Department of Chemistry, Faculty of Science, University of Urmia, Urmia 57153, Iran \\ ${ }^{b}$ The School of Chemistry, The University of Manchester, Manchester M13 9PL, UK \\ ${ }^{c}$ Islamic Azad University Khoy Branch, Khoy, West Azarbayjan, Iran \\ E-mail:john.joule@manchester.ac.uk
}

\begin{abstract}
cis,cis-1,5-Cyclooctadiene is the starting point for the synthesis of quinoxaline- and pyrazinecontaining heterocycles with three, four or five rings in linear arrays with a central eightmembered carbocyclic ring.
\end{abstract}

Keywords: cis,cis-1,5-Cyclooctadiene, quinoxaline, pyrazine, pyrido[2,3-b]pyrazine

\section{Introduction}

cis,cis-1,5-Cyclooctadiene is a commercially available and inexpensive starting material. It has been utilised previously in several significant ways, for example as the starting material for the synthesis of 9-borabicyclo[3.3.1]nonane (9-BBN) the important hydroborating reagent, as a ligand (COD) for metal centres, for conversion into 1,3,5-cyclooctatriene (COT) also a widely used ligand, and for the study of transannular interactions involving the two alkene units. Our interest in the synthesis of heterocycles, and pyrazines and quinoxalines in particular, led us to speculate that this eight-membered ring bis-alkene could be made the starting point for the construction of diverse novel heterocycles, but avoiding any transannular processes which would remove the eight-membered feature.

Before our work, only isolated examples of cycloocta[b]quinoxalines or cycloocta $[b]$ pyrazines had been described, obtained by diverse routes which cannot be considered general. For example, trimethyl 6H-8,9,10,11-tetrahydrocyclocta[b]quinoxaline7,7,10-tricarboxylate $\mathbf{3}$ had been prepared by a base-catalysed condensation reaction of 2,3bis(bromomethyl)quinoxaline 1 with dimethyl 2-oxocyclopentane-1,3-dicarboxylate ${ }^{1}$ via reverse $^{2}$ Claisen cleavage of the immediate tetracyclic intermediate 2 , which was later isolated ${ }^{2}$ from a comparable condensation (Scheme 1). 


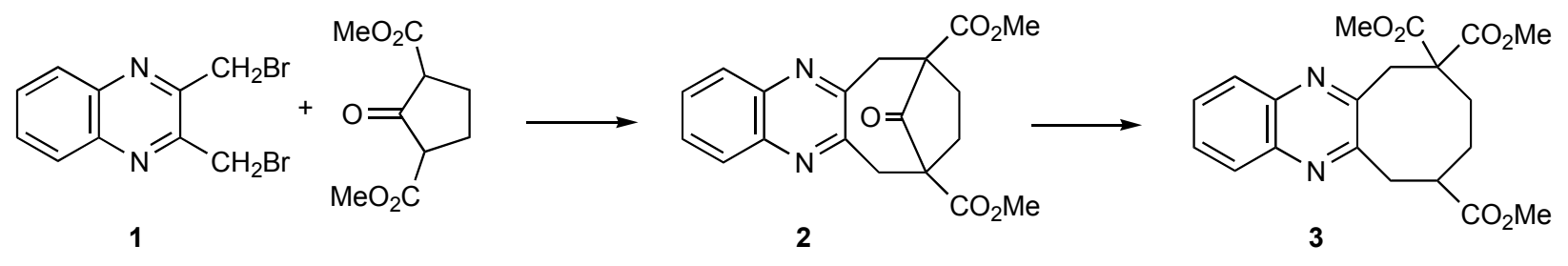

\section{Scheme 1}

Pyrolysis of the quinoxaline-sultines 4 in the presence of excess $N$-phenylmaleimide produced the cis- and trans-isomers of the $2+1$ bis-imide adducts 5 (Scheme 2). ${ }^{3}$<smiles>O=S1Cc2nc3ccccc3nc2CO1</smiles>

4<smiles>O=C1C=CC(=O)N1c1ccccc1</smiles><smiles>CCCCCCC</smiles><smiles>O=C1C2Cc3nc4ccccc4nc3C[C@H]3C(=O)N(c4ccccc4)C(=O)[C@H]3C2C(=O)N1c1ccccc1</smiles>

\section{Scheme 2}

Strong heating (Bunsen burner; open vessel) of the sulfone 6 produced a low yield of the tetraphenyl-substituted cycloocta[1,2-b:5,6-b ]diquinoxaline 7 (Scheme 3). ${ }^{4}$<smiles>O=S1(=O)C(c2ccccc2)c2nc3ccccc3nc2C1c1ccccc1</smiles>

6<smiles>c1ccc(C2c3nc4ccccc4nc3C(c3ccccc3)C(c3ccccc3)c3nc4ccccc4nc32)cc1</smiles>

7

\section{Scheme 3}

The bis- $N$-oxide 9 of $6,7,8,9,10,11$-hexahydrocyclocta[b]quinoxaline was reduced to the corresponding quinoxaline $\mathbf{1 0}$ with sodium dithionite. ${ }^{5}$ Treatment with sodium borohydride also resulted in deoxygenation but in addition reduction of the pyrazine ring to give $5,5 \mathrm{a}, 6,7,8,9,10,11,11 \mathrm{a}, 12$-decahydrocyclocta[b]quinoxaline. ${ }^{6}$ The bis- $N$-oxide is available from the reaction of 2,1,3-benzoxazadiazole 1-oxide $\mathbf{8}$ (benzofurazan 1-oxide) with the morpholine enamine of cycloctanone (Scheme 4$){ }^{7}$ 


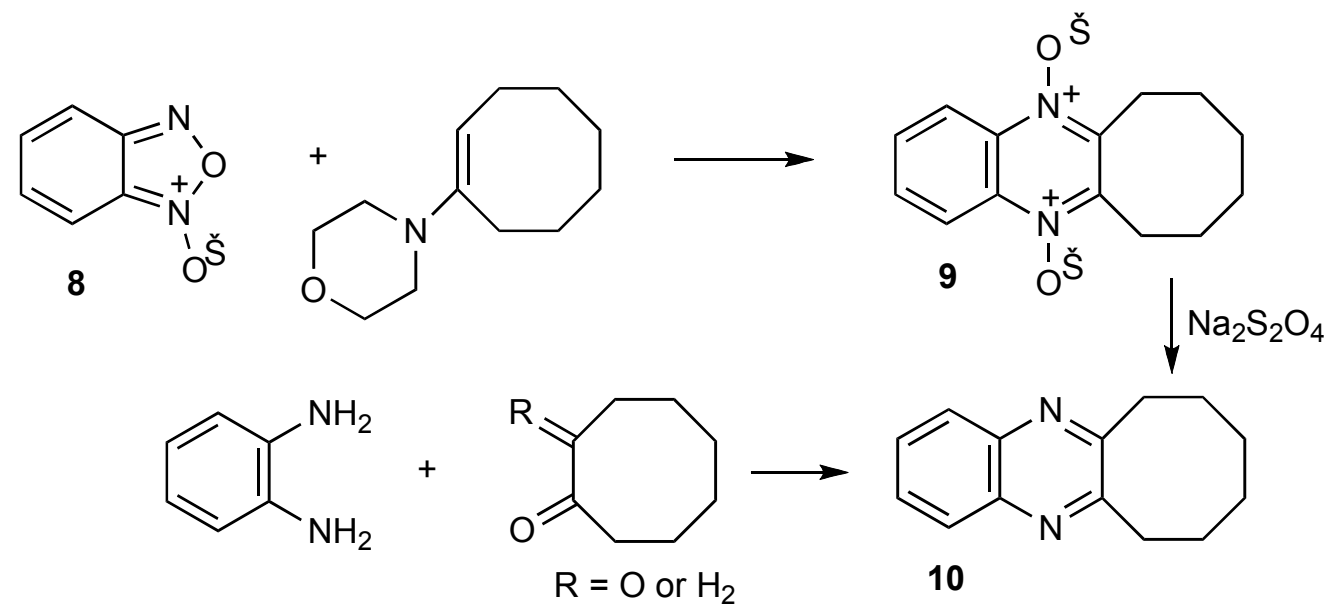

\section{Scheme 4}

$6,7,8,9,10,11-$ Hexahydrocyclocta[$[b]$ quinoxaline $\mathbf{1 0}$ is produced more simply either by the reaction of cyclooctane-1,2-dione ('suberil') with ortho-phenylenediamine, though minimal details were given in the publication describing this route, ${ }^{8}$ or most simply of all, as recently reported, by the reaction of cyclooctanone with ortho-phenylenediamine in the presence of $\mathrm{KOH}$ and air in PEG-400 at $60{ }^{\circ} \mathrm{C} .{ }^{9}$

The only reported cycloocta $[b]$ pyrazine is $\mathbf{1 2}$, obtained in trace amounts by reacting the bispyrazine 11 with lithium diisopropylamide (LDA) and then with 1,2-dibromoethene (Scheme 5). ${ }^{10}$<smiles>Cc1nccnc1CCc1nccnc1C</smiles>

11

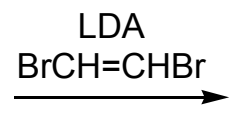<smiles>c1cnc2c(n1)CCc1nccnc1CC2</smiles>

12

\section{Scheme 5}

\section{Results and Discussion}

cis,cis-Cycloocta-1,5-diene was dihydroxylated, following earlier work, ${ }^{11}$ by reaction with a mixture of hydrogen peroxide (33\%) and formic acid at $40-45{ }^{\circ} \mathrm{C}$ giving 13 in $39 \%$ yield. Oxidation of the diol using dimethylsulfoxide activated with acetic anhydride produced the dione 14 (31\% yield) and reaction of this with ortho-phenylenediamine in refluxing acetic acid gave the quinoxaline 15 in $88 \%$ yield (Scheme 6), these last two steps also having been described previously. ${ }^{11}$ 


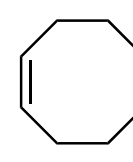

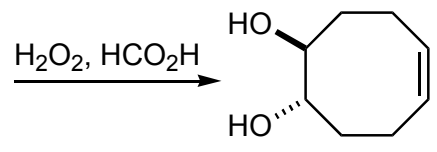

13
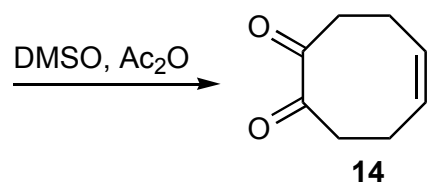
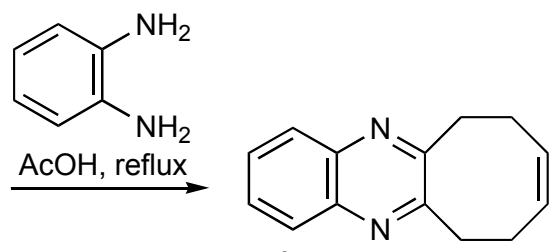

15

\section{Scheme 6}

Our next intention was to convert the remaining carbon-carbon double bond in $\mathbf{1 5}$ into a 1,2dione so that a second heterocycle could be added. We attempted this transformation by utilizing a combination of $\mathrm{KMnO}_{4}, \mathrm{CuSO}_{4} .5 \mathrm{H}_{2} \mathrm{O}$ in a mixture of $t-\mathrm{BuOH}, \mathrm{CH}_{2} \mathrm{Cl}_{2}$ and water as recommended $^{12}$ for the conversion of alkene into 1,2-dione. However, in our hands, with substrate 15 this procedure gave the 2-hydroxy-ketone 16 in 60\% yield (Scheme 7). However, using a different oxidizing combination $-\mathrm{KMnO}_{4}, \mathrm{CuSO}_{4} .5 \mathrm{H}_{2} \mathrm{O}, \mathrm{Cu}(\mathrm{OAc})_{2}$, in $t-\mathrm{BuOH} / \mathrm{H}_{2} \mathrm{O}-$ did produce the desired 1,2-dione 17 in $40 \%$ yield.

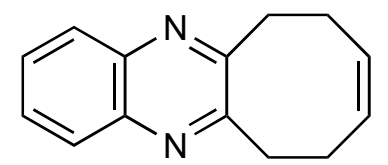

15
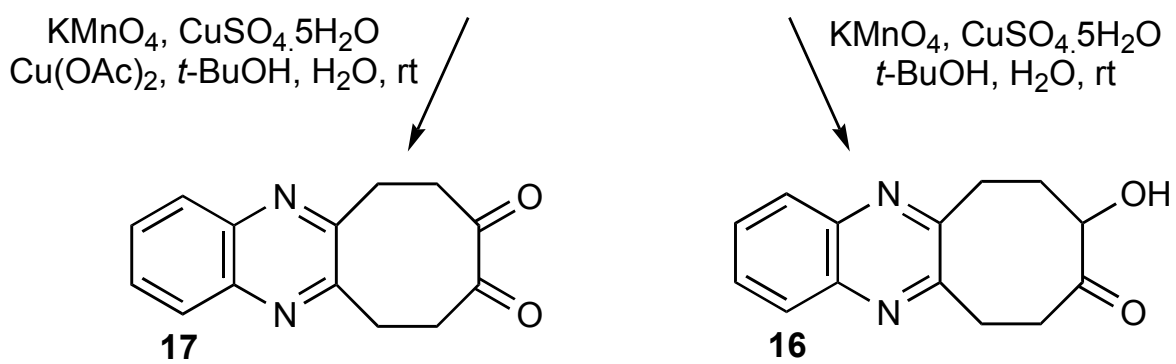

\section{Scheme 7}

The hydroxy-ketone 16 was nicely crystalline and we took the opportunity to determine its solid-state structure by an X-ray analysis. Experimental details and atomic co-ordinates are given in the Experimental Section and a Chem3D representation, taken from the atomic co-ordinates, is shown in Figure 1. 


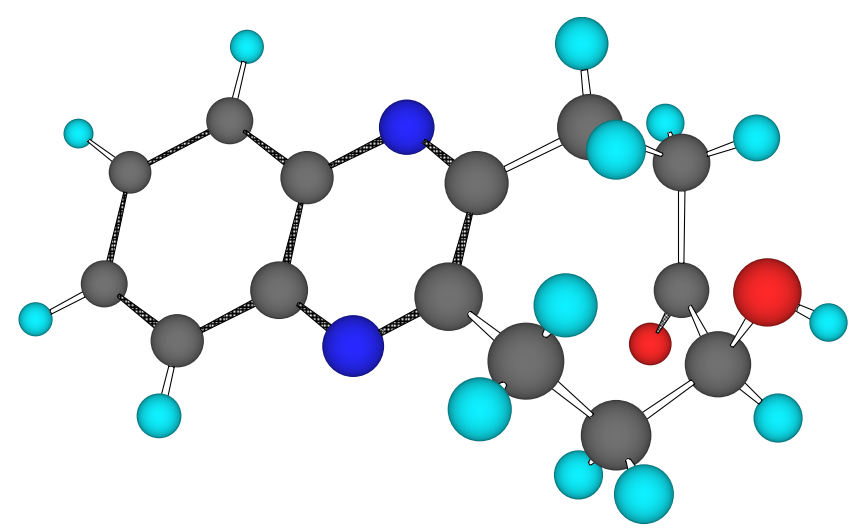

Figure 1. Chem3D representation of hydroxy-ketone $\mathbf{1 6}$ taken from the measured atomic coordinates.

There are many reported crystal structures of $\alpha$-hydroxy-ketones (2-hydroxy-ketones) but none of these include this feature in a five-, six-, seven- or eight-membered ring. It is then of considerable interest that in the present structure, the relative orientations of the $\mathrm{C}-\mathrm{OH}$ and $\mathrm{C}=\mathrm{O}$ bonds are very nearly completely antiperiplanar - the dihedral angle is $172.0(5)^{\circ}$. This relative orientation is seen in acyclic 2-hydroxy-ketone structures, but it is significant that the steric constraints placed on the hydroxy-ketone unit by the eight-membered ring, and its fusion to an essentially planar quinoxaline, do not perturb a strong tendency for the two carbon-oxygen bonds to orient antiperiplanar, thus minimizing dipole-dipole interaction.

The 1,2-diketone $\mathbf{1 7}$ was reacted with ortho-phenylenediamine in refluxing acetic acid producing the pentacycle $\mathbf{1 8}$ in $\mathbf{7 5 \%}$ yield. A comparable reaction with 2,3-diaminopyridine, again in refluxing acetic acid, produced the five-nitrogen pentacycle 19, in 60\% yield. Finally in this series, reaction with diaminomaleonitrile, also in hot acetic acid, gave the dinitrile $\mathbf{2 0}$ in a yield of $75 \%$ (Scheme 8). In each case, the continued presence of the eight-membered ring was evidenced by signals for eight benzylic-type hydrogens in the range $\delta 3.77$ to 3.96.

The alkene-diol 13 was converted into dione-diacetate 22 (Scheme 9) by first, protection of the hydroxyl groups, forming the diacetate ${ }^{11} \mathbf{2 1}$, and then application of the same oxidising combination as had been successful for the synthesis of $\mathbf{1 7}$. 


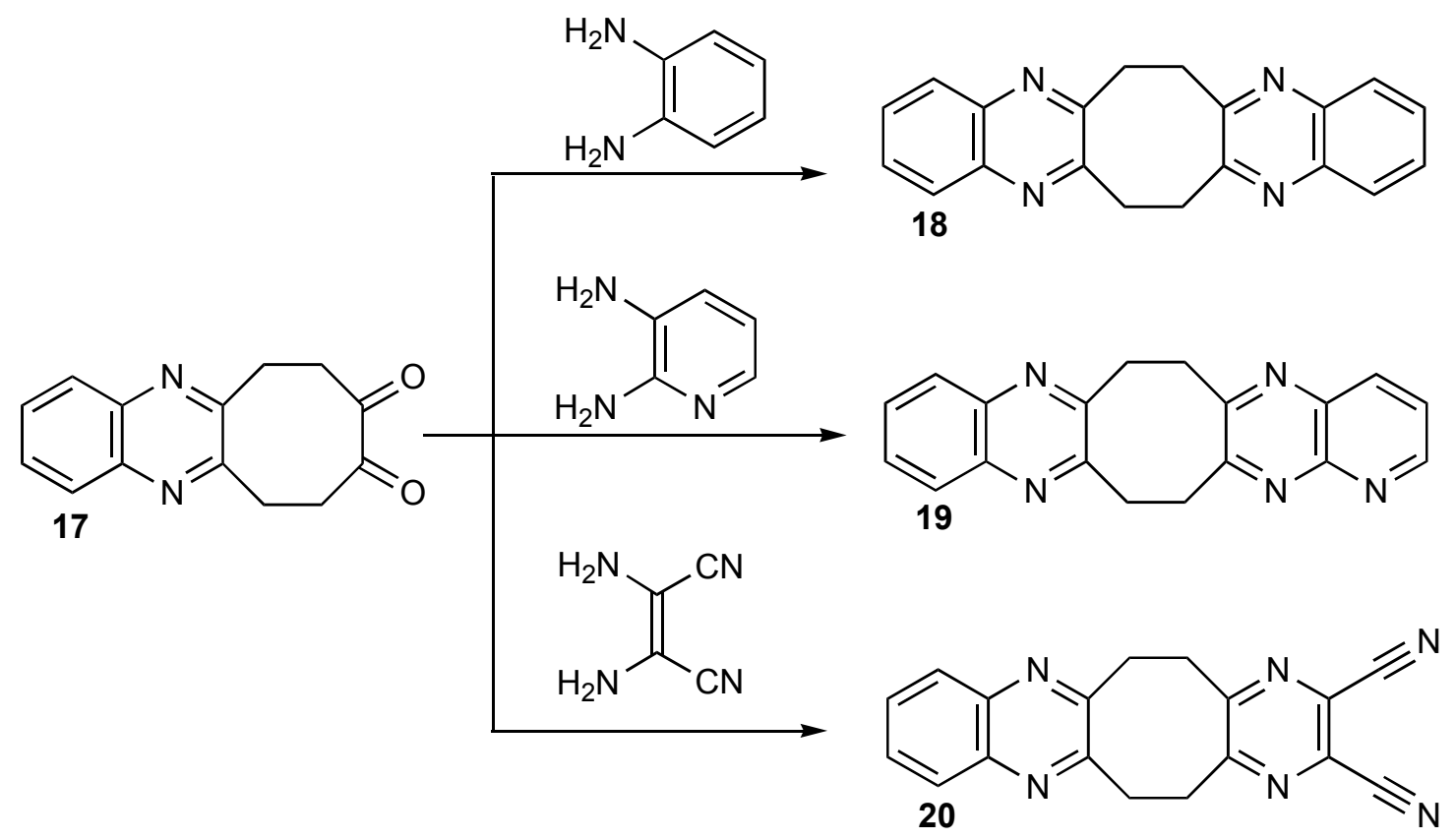

\section{Scheme 8}

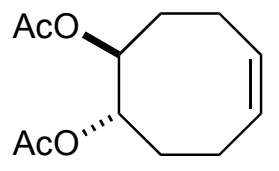

21
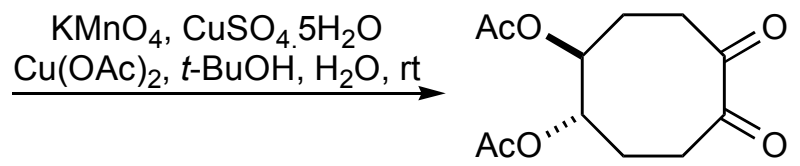

22

\section{Scheme 9}

Exposure of the dione-diacetate 22 to the standard conditions we had used for preparing the other quinoxalines - ortho-phenylenediamine in refluxing acetic acid - produced the tricyclic diacetate $\mathbf{2 3}$, in $75 \%$ yield, without loss of either acetate unit. The structure of product $\mathbf{2 3}$ was verified by a single crystal X-ray analysis. ${ }^{13}$ The dione-diacetate reacted equally well with 2,3diaminopyridine and diaminomaleonitrile to form the cycloocta[1,2-b]pyrido[2,3-e]pyrazine 24 and the bicyclic pyrazine 25 respectively (Scheme 10). 


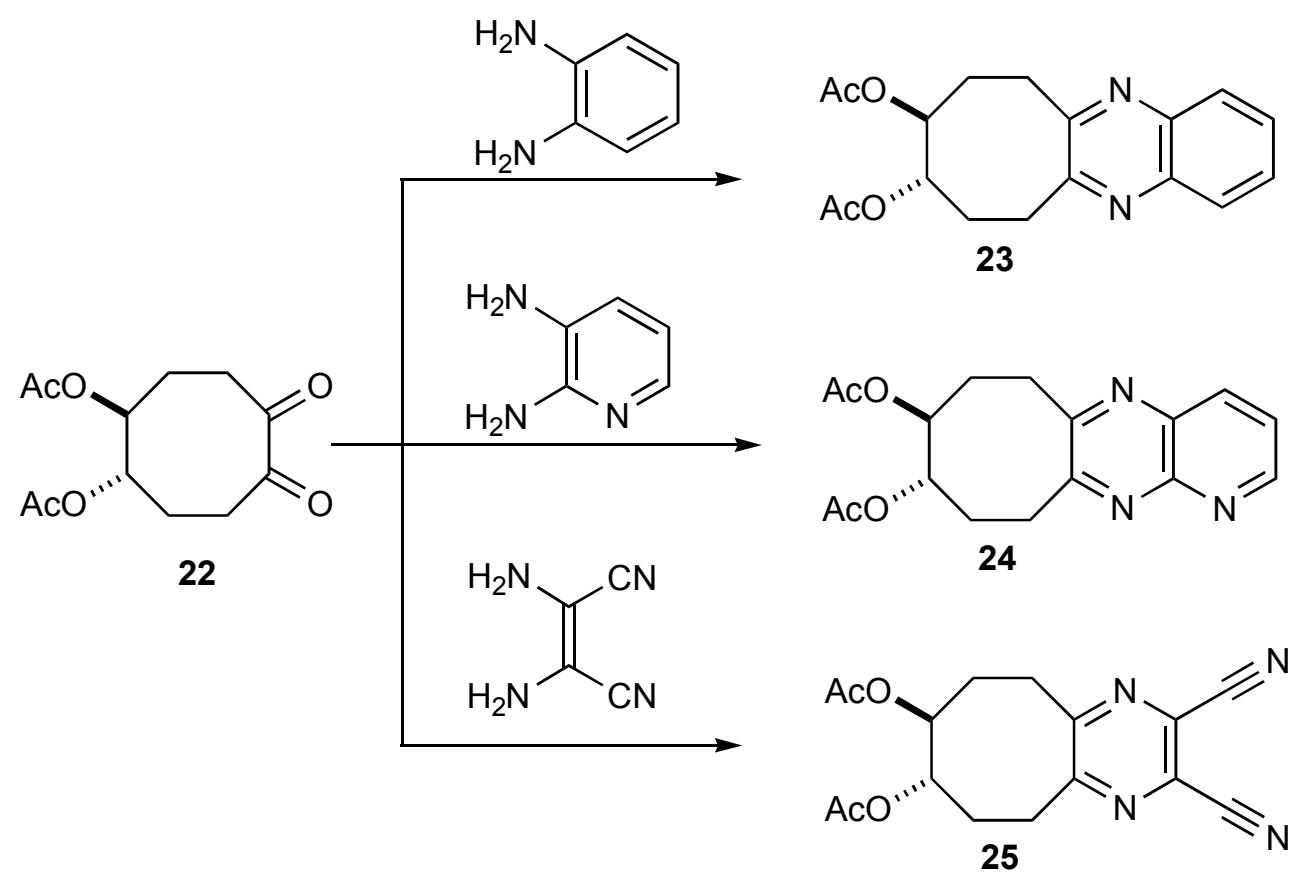

Scheme 10

\section{Conclusions}

The further chemistry of the eight-membered ring-containing quinoxalines, pyrido[2,3$b]$ pyrazines, and pyrazines described in this paper is the subject of continuing study, particularly of those with functional groups (alcoholic acetates and nitriles) and our further results will be described in due course.

\section{Experimental Section}

General Procedures. All substrates were purchased from Merck and used without further purification. Melting points were determined on a digital melting point apparatus (electrothermal) and are uncorrected. Infrared spectra were recorded on a Thermonicolet (Nexus 670) FT-infrared spectrometer, using sodium chloride cells and measured as Nujol mulls or $\mathrm{KBr}$ discs. ${ }^{1} \mathrm{H}(300 \mathrm{MHz})$ and ${ }^{13} \mathrm{C}(75.5 \mathrm{MHz})$ NMR measurements were recorded on a Bruker 300 spectrometer in $\mathrm{CDCl}_{3}$ using TMS as the internal reference. High resolution mass spectra were recorded on an Agilent Technology (HP), MS Model: 5973 Network Mass, selective Detector Ion source: Electron Impact (EI) $70 \mathrm{eV}$, Ion source temperature: $230{ }^{\circ} \mathrm{C}$ Analyzer: quadrupole, Analyzer temperature: $150^{\circ} \mathrm{C}$ and relative abundances of fragments are quoted in parentheses after the $m / z$ values. 


\section{6,7,10,11-Tetrahydrocycloocta $[b]$ quinoxaline 15}

cis-5-Cyclooctene-1,2-dione (1.00 g, $7.25 \mathrm{mmol})$, ortho-phenylenediamine (0.784 g, $7.24 \mathrm{mmol})$, and acetic acid $(18 \mathrm{ml})$ were heated on the steam bath for $1 \mathrm{~h}$. Water $(c a .60 \mathrm{ml})$ was added to the hot solution until it was slightly cloudy, and the solution was allowed to cool. The solution deposited almost colorless needles of compound 15 (1.33 g, 88\%) m.p. $118-119{ }^{\circ} \mathrm{C}$. ${ }^{1} \mathrm{H} \mathrm{NMR}$ $\left(\mathrm{CDCl}_{3}\right) \delta 2.74(\mathrm{q}, J=7.2 \mathrm{~Hz}, 4 \mathrm{H}), 3.42(\mathrm{t}, J=7.2 \mathrm{~Hz}, 4 \mathrm{H}), 5.50(\mathrm{~m}, 2 \mathrm{H}), 7.68$ (dd, $J=6.3,3.3 \mathrm{~Hz}$, $2 \mathrm{H}, \mathrm{Ar}), 8.02(\mathrm{dd}, J=6.3,3.3 \mathrm{~Hz}, 2 \mathrm{H}, \mathrm{Ar}) ;{ }^{13} \mathrm{C} \mathrm{NMR}\left(\mathrm{CDCl}_{3}\right) \delta 27.1,35.6,128.3,128.9,129.1$, 146.81, 157.1; FT-IR (KBr) $v_{\max } / \mathrm{cm}^{-1}: 3421,3014,2886,1485,761$.

\section{6,7,8,9,10,11-Hexahydro-9-hydroxycycloocta[b]quinoxalin-8-one 16}

A stirred mixture of $\mathrm{KMnO}_{4}(4.0 \mathrm{~g}), \mathrm{CuSO}_{4} .5 \mathrm{H}_{2} \mathrm{O}(2.0 \mathrm{~g})$, and water $(200 \mathrm{~mL})$ in ichloromethane $(15 \mathrm{~mL})$ was reacted with cyclooctene $15(0.552 \mathrm{~g}, 4 \mathrm{mmol})$ in dichloromethane $(5 \mathrm{~mL})$ followed by tert-butyl alcohol $(1 \mathrm{~mL})$ at $25{ }^{\circ} \mathrm{C}$. After $0.5 \mathrm{~h}$, the reaction mixture was filtered, and solvent was removed to yield $16(0.38 \mathrm{~g}, 60 \%)$ as the only product, Mp 187-189 ${ }^{\circ} \mathrm{C} .{ }^{1} \mathrm{H}$ NMR (DMSO$\left.\mathrm{d}_{6}\right) \delta 1.83(\mathrm{~m}, 1 \mathrm{H}), 2.12(\mathrm{~m}, 1 \mathrm{H}), 2.30(\mathrm{~m}, 1 \mathrm{H}), 2.92(\mathrm{~m}, 1 \mathrm{H}), 3.13(\mathrm{~m}, 1 \mathrm{H}), 3.45(\mathrm{~m}, 2 \mathrm{H}), 3.95$ $(\mathrm{m}, 1 \mathrm{H}), 4.1(\mathrm{~s}, 1 \mathrm{H}), 5.89(\mathrm{~s}, 1 \mathrm{H}), 7.74(\mathrm{~d}, J=6 \mathrm{~Hz}, 2 \mathrm{H}), 7.96(\mathrm{~d}, J=6 \mathrm{~Hz}, 2 \mathrm{H}) ;{ }^{13} \mathrm{C} \mathrm{NMR}\left(\mathrm{CDCl}_{3}\right)$ $\delta 30.3,30.6,34.4,43.4,75.9,128.7,128.7,129.8,129.9,141.1,141.2,156.3,157.3,210.1$; FTIR $(\mathrm{KBr}) v_{\max } / \mathrm{cm}^{-1}: 3248,1701,763$.

Single crystals of the hydroxy-ketone $\mathbf{1 6}$ were grown from ethyl acetate. Intensity data were measured from a colourless crystal measuring $0.40 \mathrm{x} 0.10 \mathrm{x} 0.05 \mathrm{~mm}$.

\section{Crystal data}

Formula, $\mathrm{C}_{14} \mathrm{H}_{14} \mathrm{~N}_{2} \mathrm{O}_{2}$; Formula weight, 242.2; Crystal system: monoclinic; Space group: $\mathrm{P} 2{ }_{1} / \mathrm{n}$; $Z=4 ; a=6.305(3) \AA ; b=11.054(4) \AA ; c=16.150(6) \AA ; \beta=94.282(7)^{\circ} ; V=1122.5(8) \AA 3 ; D$ (calc.) $=1.434 \mathrm{Mg} / \mathrm{m}^{3} ;$ Absorption coefficient $0.098 \mathrm{~mm}^{-1} ; \mathrm{F}(000)$ 512; Crystal size, $0.40 \times 0.10 \times 0.05 \mathrm{~mm} ; \theta$ range for data collection 2.23 to $25.03^{\circ}$; Index ranges $-7<=\mathrm{h}<=7$, $13<=\mathrm{k}<=10,-19<=1<=18$; Reflections collected 5630; Independent reflections $1977 \quad$ [R(int) = 0.1347]; Completeness to $\theta=25.03^{\circ} 99.6 \%$; Refinement method, Full-matrix least-squares on $\mathrm{F}^{2}$; Data / restraints / parameters, 1977 / 0 / 164; Goodness-of-fit on $\mathrm{F}^{2}, 0.950$; Final R indices $[\mathrm{I}>2 \sigma(\mathrm{I})], \mathrm{R} 1=0.0865, \mathrm{wR} 2=0.2234 ; \mathrm{R}$ indices $\left(\right.$ all data), $\mathrm{R} 1=0.1460, \mathrm{wR} 2=0.2514 ;(\Delta \sigma)_{\max }$ $0.000 ;(\Delta \sigma)_{\max }$ and $(\Delta \sigma)_{\min }, 0.991$ and $-0.433 \mathrm{e}^{-3}$.

Measurement, BRUKER APEX CCD diffractometer; Structure determination, SHELLXS-97; Refinement, SHELXL-97; Program system, SAINT and SHELXTL; Hydrogen atom treatment, included in calculated positions using the riding method. 


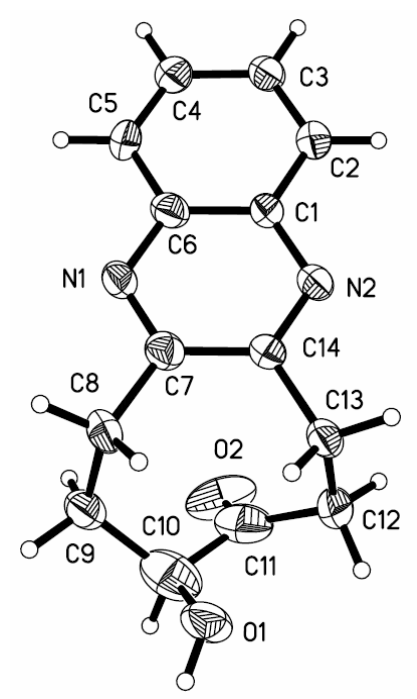

Figure 2. ORTEP drawing of 6,7,8,9,10,11-hexahydro-9-hydroxycycloocta[b]quinoxalin-8-one 16 showing the atomic labelling system used in the Tables.

Table 1. Atomic coordinates $\left(\times 10^{4}\right)$ and equivalent isotropic displacement parameters $\left(\AA^{2} \times 10^{3}\right)$. $\mathrm{U}(\mathrm{eq})$ is defined as one third of the trace of the orthogonalized $\mathrm{U}^{\mathrm{ij}}$ tensor

\begin{tabular}{ccccc}
\hline & $x$ & $y$ & $z$ & $\mathrm{U}(\mathrm{eq})$ \\
\hline $\mathrm{O}(1)$ & $11764(6)$ & $11834(3)$ & $2144(2)$ & $48(1)$ \\
$\mathrm{O}(2)$ & $7716(7)$ & $9662(4)$ & $1858(2)$ & $66(1)$ \\
$\mathrm{N}(1)$ & $10788(6)$ & $8182(4)$ & $3891(2)$ & $31(1)$ \\
$\mathrm{N}(2)$ & $7676(6)$ & $9802(3)$ & $4315(2)$ & $29(1)$ \\
$\mathrm{C}(1)$ & $7621(7)$ & $8627(4)$ & $4558(3)$ & $28(1)$ \\
$\mathrm{C}(2)$ & $5964(7)$ & $8219(4)$ & $5017(3)$ & $32(1)$ \\
$\mathrm{C}(3)$ & $5894(8)$ & $7035(4)$ & $5254(3)$ & $33(1)$ \\
$\mathrm{C}(4)$ & $7428(8)$ & $6223(4)$ & $5015(3)$ & $37(1)$ \\
$\mathrm{C}(5)$ & $9037(8)$ & $6597(4)$ & $4565(3)$ & $36(1)$ \\
$\mathrm{C}(6)$ & $9165(7)$ & $7809(4)$ & $4331(3)$ & $32(1)$ \\
$\mathrm{C}(7)$ & $10845(8)$ & $9315(5)$ & $3665(3)$ & $32(1)$ \\
$\mathrm{C}(8)$ & $12668(7)$ & $9698(4)$ & $3187(3)$ & $33(1)$ \\
$\mathrm{C}(9)$ & $12225(8)$ & $9611(5)$ & $2250(3)$ & $40(1)$ \\
$\mathrm{C}(10)$ & $10808(10)$ & $10658(6)$ & $1885(4)$ & $64(2)$ \\
$\mathrm{C}(11)$ & $8672(10)$ & $10563(6)$ & $2143(3)$ & $57(2)$ \\
$\mathrm{C}(12)$ & $7933(9)$ & $11510(5)$ & $2723(3)$ & $44(1)$ \\
$\mathrm{C}(13)$ & $9137(8)$ & $11414(4)$ & $3570(3)$ & $34(1)$ \\
$\mathrm{C}(14)$ & $9221(7)$ & $10140(4)$ & $3881(3)$ & $28(1)$ \\
\hline
\end{tabular}

Table 2. Selected torsion angles $\left[{ }^{\circ}\right]$

$\begin{array}{llll}\mathrm{C}(6) & \mathrm{N}(1) & \mathrm{C}(7) & \mathrm{C}(8)\end{array}$




\begin{tabular}{ccccc}
$\mathrm{N}(1)$ & $\mathrm{C}(7)$ & $\mathrm{C}(8)$ & $\mathrm{C}(9)$ & $91.8(5)$ \\
$\mathrm{C}(14)$ & $\mathrm{C}(7)$ & $\mathrm{C}(8)$ & $\mathrm{C}(9)$ & $88.8(6)$ \\
$\mathrm{C}(7)$ & $\mathrm{C}(8)$ & $\mathrm{C}(9)$ & $\mathrm{C}(10)$ & $76.8(6)$ \\
$\mathrm{C}(8)$ & $\mathrm{C}(9)$ & $\mathrm{C}(10)$ & $\mathrm{C}(11)$ & $68.4(6)$ \\
$\mathrm{C}(8)$ & $\mathrm{C}(9)$ & $\mathrm{C}(10)$ & $\mathrm{O}(1)$ & $54.1(6)$ \\
$\mathrm{O}(1)$ & $\mathrm{C}(10)$ & $\mathrm{C}(11)$ & $\mathrm{O}(2)$ & $172.0(5)$ \\
$\mathrm{C}(9)$ & $\mathrm{C}(10)$ & $\mathrm{C}(11)$ & $\mathrm{O}(2)$ & $66.0(6)$ \\
$\mathrm{O}(1)$ & $\mathrm{C}(10)$ & $\mathrm{C}(11)$ & $\mathrm{C}(12)$ & $9.8(7)$ \\
$\mathrm{C}(9)$ & $\mathrm{C}(10)$ & $\mathrm{C}(11)$ & $\mathrm{C}(12)$ & $112.2(6)$ \\
$\mathrm{O}(2)$ & $\mathrm{C}(11)$ & $\mathrm{C}(12)$ & $\mathrm{C}(13)$ & $110.4(6)$ \\
$\mathrm{C}(10)$ & $\mathrm{C}(11)$ & $\mathrm{C}(12)$ & $\mathrm{C}(13)$ & $67.5(6)$ \\
$\mathrm{C}(11)$ & $\mathrm{C}(12)$ & $\mathrm{C}(13)$ & $\mathrm{C}(14)$ & $47.7(6)$ \\
$\mathrm{C}(1)$ & $\mathrm{N}(2)$ & $\mathrm{C}(14)$ & $\mathrm{C}(13)$ & $175.5(4)$ \\
$\mathrm{C}(8)$ & $\mathrm{C}(7)$ & $\mathrm{C}(14)$ & $\mathrm{N}(2)$ & $178.2(4)$ \\
$\mathrm{N}(1)$ & $\mathrm{C}(7)$ & $\mathrm{C}(14)$ & $\mathrm{C}(13)$ & $174.6(4)$ \\
$\mathrm{C}(8)$ & $\mathrm{C}(7)$ & $\mathrm{C}(14)$ & $\mathrm{C}(13)$ & $6.1(7)$ \\
$\mathrm{C}(12)$ & $\mathrm{C}(13)$ & $\mathrm{C}(14)$ & $\mathrm{N}(2)$ & $89.8(5)$ \\
$\mathrm{C}(12)$ & $\mathrm{C}(13)$ & $\mathrm{C}(14)$ & $\mathrm{C}(7)$ & $86.2(5)$ \\
\hline
\end{tabular}

There are strong $\mathrm{H}$ bonding interactions between $\mathrm{O}(1)$ and $\mathrm{N}(1)$ which link the molecules into chains (Table 3 and Figure 3). In addition, there are weaker $\mathrm{C}-\mathrm{H}^{\cdots}{ }^{\cdots} \mathrm{N}$ pairwise interactions between $\mathrm{C}(2)$ and $\mathrm{N}(2)$ (Table 3, Fig 3) as well as $\pi$ - $\pi$ stacking interactions between the ring $\mathrm{N}(1)-\mathrm{C}(6)-\mathrm{C}(1)-\mathrm{N}(2)-\mathrm{C}(14)-\mathrm{C}(7)$ and its symmetry equivalent at $(2-\mathrm{x}, 2-\mathrm{y}, 1-\mathrm{z})$, with a centroidcentroid distance of 3.737(3) $\AA$ and a perpendicular distance of $3.307 \AA$.

Table 3. Hydrogen bonds for hydroxy-ketone 2 [ $\AA$ and $\left.{ }^{\circ}\right]$

\begin{tabular}{ccccc}
\hline D-H...A & $\mathrm{d}(\mathrm{D}-\mathrm{H})$ & $\mathrm{d}(\mathrm{H} \ldots \mathrm{A})$ & $\mathrm{d}(\mathrm{D} \ldots \mathrm{A})$ & $<(\mathrm{DHA})$ \\
\hline $\mathrm{O}(1)-\mathrm{H}(1) \ldots \mathrm{N}(1) \# 1$ & 0.84 & 1.98 & $2.789(5)$ & 161.8 \\
$\mathrm{C}(2)-\mathrm{H}(2) \ldots \mathrm{N}(2) \#$ & 0.95 & 2.46 & $3.406(6)$ & 174.1 \\
\hline
\end{tabular}

Symmetry transformations used to generate equivalent atoms:

$\# 1-\mathrm{x}+5 / 2, \mathrm{y}+1 / 2,-\mathrm{z}+1 / 2 \quad \# 2-\mathrm{x}+1,-\mathrm{y}+2,-\mathrm{z}+1$ 


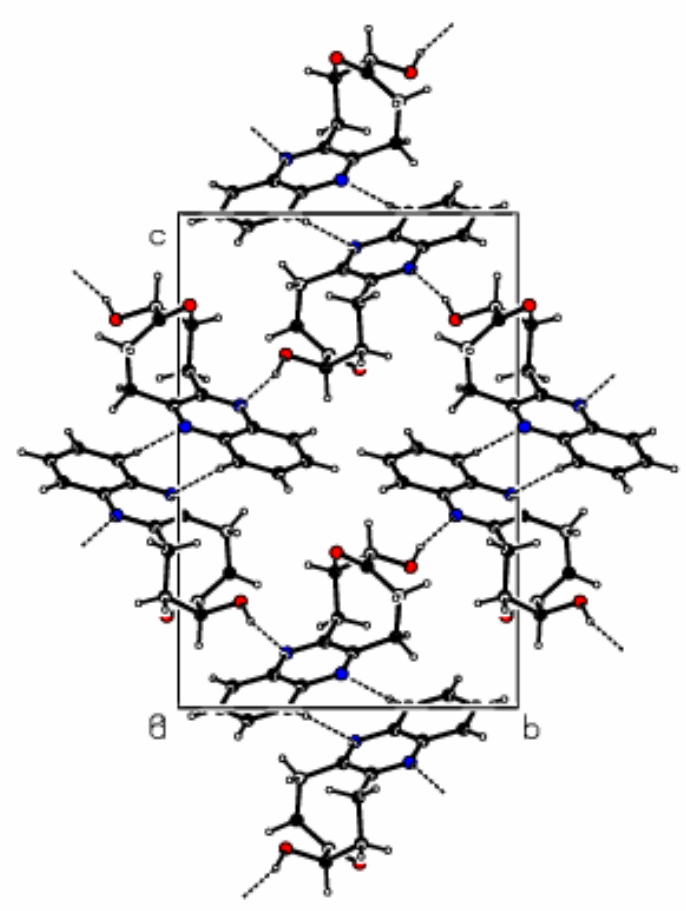

Figure 3. Packing diagram for $\mathbf{1 6}$ viewed down the a axis. Intermolecular hydrogen bonding interactions are shown with dotted lines.

\section{6,7,8,9,10,11-Hexahydrocycloocta[b]quinoxaline-8,9-dione 17}

To a mixture of $\mathrm{KMnO}_{4}(4.0 \mathrm{~g}), \mathrm{CuSO}_{4} .5 \mathrm{H}_{2} \mathrm{O}(2.0 \mathrm{~g})$, and water $(300 \mathrm{~mL})$ in dichloromethane $(15 \mathrm{~mL})$ was added solid $\mathrm{Cu}(\mathrm{OAc})_{2} \cdot \mathrm{H}_{2} \mathrm{O}(1.0 \mathrm{~g})$ and $\mathbf{1 5}(0.276 \mathrm{~g}, 2 \mathrm{mmol})$ in dichloromethane $(5$ $\mathrm{mL})$, and tert-butyl alcohol $(1 \mathrm{~mL})$. After $12 \mathrm{~h}$, the reaction mixture was filtered, and solvent was removed to yield dione $17(0.126 \mathrm{~g}, 40 \%)$ as the only product, $\mathrm{Mp} 182-185^{\circ} \mathrm{C} .{ }^{1} \mathrm{H}$ NMR $\left(\mathrm{CDCl}_{3}\right) \delta 3.02(\mathrm{t}, J=6.45 \mathrm{~Hz}, 4 \mathrm{H}), 3.45(\mathrm{t}, J=6.45 \mathrm{~Hz}, 4 \mathrm{H}), 7.76(\mathrm{~d}, J=6.3,2 \mathrm{H}), 8.03(\mathrm{~d}, J=6.3$, $2 \mathrm{H}) ;{ }^{13} \mathrm{C} \mathrm{NMR}\left(\mathrm{CDCl}_{3}\right) \delta 31.6,39.6,128.7,130.2,141.7,153.0,206.4$. FT-IR $(\mathrm{KBr}) v_{\max } / \mathrm{cm}^{-1}$ : 2923, 1703. MS (EI, $70 \mathrm{ev):} \mathrm{m} / z(\%) 240\left(\mathrm{M}^{+}, 60\right), 212$ (30), 183 (100), 169 (86). Found: $\mathrm{M}^{+}$; $240.0900, \mathrm{C}_{14} \mathrm{H}_{12} \mathrm{~N}_{2} \mathrm{O}_{2}$ requires $\mathrm{M}^{+} 240.0899$.

\section{6,7,14,15-Tetrahydrocycloocta[1,2-b:5,6-b']diquinoxaline 18}

A mixture of the dione $17(0.15 \mathrm{~g}, 0.625 \mathrm{mmol})$ and $o$-phenylenediamine $(0.07 \mathrm{~g}, 0.64 \mathrm{mmol})$ was refluxed in $\mathrm{AcOH}(10 \mathrm{~mL})$ for $6 \mathrm{~h}$. The product precipitated from the reaction mixture. The mixture was cooled, the product filtered off and washed with water, to give $18(0.14 \mathrm{~g}, 75 \%)$. Mp $>300{ }^{\circ} \mathrm{C} .{ }^{1} \mathrm{H}$ NMR $\left(\mathrm{CDCl}_{3}\right) \delta 3.77(\mathrm{~s}, 8 \mathrm{H}), 8.11(\mathrm{br}, \mathrm{s}, 4 \mathrm{H}), 8.25(\mathrm{br}, \mathrm{s}, 4 \mathrm{H}) ;{ }^{13} \mathrm{C} \mathrm{NMR}\left(\mathrm{CDCl}_{3}+\right.$ $\left.\mathrm{CF}_{3} \mathrm{CO}_{2} \mathrm{H}\right) \delta 31.6,124.7,135.3,136.3,152.8$. FT-IR (KBr) $v_{\max } / \mathrm{cm}^{-1}: 2930,774$. MS (EI, 70 ev): $m / z(\%) 312\left(\mathrm{M}^{+}, 93\right), 297(100)$. Found: $\mathrm{M}^{+} ; 312.1376 \mathrm{C}_{20} \mathrm{H}_{16} \mathrm{~N}_{4}$ requires $\mathrm{M}^{+} 312.1375$. 


\section{6,7,14,15-Tetrahydroquinoxalino[2,3-e]cycloocta[1,2-b]pyrido[2,3-e]pyrazine 19}

A mixture of the dione $17(0.15 \mathrm{~g}, 0.625 \mathrm{mmol})$ and 2,3-diaminopyridine $(0.07 \mathrm{~g}, 0.64 \mathrm{mmol})$ was refluxed in $\mathrm{AcOH}(10 \mathrm{~mL})$ for $6 \mathrm{~h}$. The product precipitated during the course of the reaction. The mixture was cooled, filtered and the precipitate washed with water, giving $19(0.14$ g, 75\%). $\mathrm{Mp}>300{ }^{\circ} \mathrm{C} .{ }^{1} \mathrm{H} \mathrm{NMR}\left(\mathrm{CDCl}_{3}+\mathrm{CF}_{3} \mathrm{CO}_{2} \mathrm{H}\right) \delta 3.77(\mathrm{br}, \mathrm{s}, 8 \mathrm{H}), 7.66(\mathrm{~d}, J=3.3 \mathrm{~Hz}, 2 \mathrm{H})$, $7.95(\mathrm{~d}, J=3.3 \mathrm{~Hz}, 2 \mathrm{H}), 7.68(\mathrm{br}, \mathrm{s}, 1 \mathrm{H}), 8.36(\mathrm{br}, \mathrm{s}, 1 \mathrm{H}), 9.03(\mathrm{br}, \mathrm{s}, 1 \mathrm{H}) ;{ }^{13} \mathrm{C} \mathrm{NMR}\left(\mathrm{CDCl}_{3}\right) \delta$ 31.7, 32.5, 34.0, 34.6, 108.8, 112.6, 116.4, 124.0, 126.5, 134.4, 134.8, 147.1, 148.3, 159.8, 160.4, 160.9, 161.5, 160.9, 163.6. FT-IR (KBr) $v_{\max } / \mathrm{cm}^{-1}: 2963,1452,762$. MS (EI, $70 \mathrm{ev):} \mathrm{m} / z(\%)$ $313\left(\mathrm{M}^{+}, 89\right), 298(100)$. Found: $\mathrm{M}^{+} ; 313.1325, \mathrm{C}_{19} \mathrm{H}_{15} \mathrm{~N}_{5}$ requires $\mathrm{M}^{+} 313.1327$.

\section{2,3-Dicyano-5,6,13,14-tetrahydroquinoxalino[2,3-e]cycloocta[2,3-e]pyrazine 20}

A mixture of the dione $17(0.15 \mathrm{~g}, 0.625 \mathrm{mmol})$ and 1,2-diaminomaleonitrile $(0.07 \mathrm{~g}, 0.64 \mathrm{mmol})$ was heated at reflux in $\mathrm{AcOH}(10 \mathrm{~mL})$ for $6 \mathrm{~h}$. The product precipitated from the reaction mixure. The mixture was cooled, filtered and the precipitate washed with water, giving $20(0.14$ g, 75\% yield. $\mathrm{Mp}>300{ }^{\circ} \mathrm{C} .{ }^{1} \mathrm{H}$ NMR $\left(\mathrm{CDCl}_{3}+\mathrm{CF}_{3} \mathrm{CO}_{2} \mathrm{H}\right) \delta 3.79(\mathrm{t}, J=6.9 \mathrm{~Hz}, 4 \mathrm{H}), 3.96(\mathrm{t}$, $J=6.9 \mathrm{~Hz}, 4 \mathrm{H}), 8.08(\mathrm{~d}, J=3.3 \mathrm{~Hz}, 2 \mathrm{H}), 8.24(\mathrm{~d}, J=3.3 \mathrm{~Hz}, 2 \mathrm{H}) .{ }^{13} \mathrm{C} \mathrm{NMR}\left(\mathrm{CDCl}_{3}\right) \delta 32.4,33.8$, 112.4, 125.6, 131.3, 134.2, 137.2, 153.1, 158.1. FT-IR (KBr) $v_{\max } / \mathrm{cm}-1: 2937,2238,776$. MS (EI, 70ev): $m / z$ (\%) $312\left(\mathrm{M}^{+}, 100\right), 297$ (89), 169 (46). Found: $\mathrm{M}^{+} ; 312.1123, \mathrm{C}_{18} \mathrm{H}_{12} \mathrm{~N}_{6}$ requires $\mathrm{M}^{+} ; 312.1123$.

\section{trans-5,6-Diacetoxycyclooctene 21}

In a 10-mL Erlenmeyer flask were placed the diol 13 (1.05 g, $7.4 \mathrm{mmol})$, acetic anhydride (6 $\mathrm{mL}$ ), and concentrated sulfuric acid (1 drop). The flask was stoppered and the mixture was left at $23{ }^{\circ} \mathrm{C}$ for $13 \mathrm{~h}$. The reaction mixture was poured into water $(30 \mathrm{~mL})$ and allowed to stand at 23 ${ }^{\circ} \mathrm{C}$ for $5 \mathrm{~h}$ with occasional swirling. The reaction mixture now consisted of a pale yellow oil beneath an aqueous layer; it was left at $2{ }^{\circ} \mathrm{C}$ for 6 days, but crystallization of the oil did not occur. The aqueous layer was extracted with $\mathrm{CH}_{2} \mathrm{Cl}_{2}$, dried, and evaporated to give a pale yellow liquid, which was combined with the oil from original reaction mixture to give the crude diacetate 21 (1.28 g, 77\%). ${ }^{1} \mathrm{H}$ NMR $\left(\mathrm{CDCl}_{3}\right) \delta 1.62(\mathrm{br}, \mathrm{s}, 2 \mathrm{H}), 1.85(\mathrm{~s}, 6 \mathrm{H}), 1.85$ (br, s, 2H), 2.052 (br, s, 2H), 2.255 (br, s, 2H), 4.939 (br, s, 2H), 5.48 (br, s, 2H).

\section{trans-5,6-Diacetoxycyclooctane-1,2-dione 22}

To a mixture of $\mathrm{KMnO}_{4}(4.0 \mathrm{~g}), \mathrm{CuSO}_{4} .5 \mathrm{H}_{2} \mathrm{O}(2.0 \mathrm{~g})$, and water $(300 \mathrm{~mL})$ in dichloromethane $(15 \mathrm{~mL})$ was added solid $\mathrm{Cu}(\mathrm{OAc})_{2} . \mathrm{H}_{2} \mathrm{O}(1.0 \mathrm{~g})$, then trans-5,6-diacetoxycyclooctene $21(0.276$ $\mathrm{g}, 2 \mathrm{mmol})$ in dichloromethane $(5 \mathrm{~mL})$, and tert-butyl alcohol $(1 \mathrm{~mL})$. After $4 \mathrm{~h}$, the reaction mixture was filtered, and solvent was removed to yield the diketone 22 as the only product (0.125 g, 40\%). ${ }^{1} \mathrm{H}$ NMR $\left(\mathrm{CDCl}_{3}\right) \delta 1.4-2.1$ (m, 14H, including $\left.\mathrm{s}, \delta 2.09\right), 2.55-2.85(\mathrm{~m}, 2 \mathrm{H})$, 4.95-5.03 (m, 2H); ${ }^{13} \mathrm{C} \mathrm{NMR}\left(\mathrm{CDCl}_{3}\right) \delta 21.2,23.5,30.7,75.7,205.1,209.3$. FT-IR $(\mathrm{KBr}) v_{\text {max }}$ $/ \mathrm{cm}^{-1}:$ 1742, 1703, 1235. MS (EI, $70 \mathrm{ev):} \mathrm{m} / z(\%) 256\left(\mathrm{M}^{+}, 30\right), 214(70 \%), 172$ (100). Found: $\mathrm{M}^{+} ; 256.0945, \mathrm{C}_{12} \mathrm{H}_{16} \mathrm{O}_{6}$ requires $\mathrm{M}^{+} ; 256.0947$. 
trans-8,9-Diacetoxy-6,7,8,9,10,11-hexahydrocycloocta[1,2-b]quinoxaline 23

A mixture of the dione $22(0.2 \mathrm{~g}, 0.625 \mathrm{mmol})$ and $o$-phenylenediamine $(0.09 \mathrm{~g}, 0.64 \mathrm{mmol})$ was heated a reflux in $\mathrm{AcOH}(10 \mathrm{~mL})$ for $3 \mathrm{~h}$. Water $(c a .10 \mathrm{~mL})$ was added and the mixture extracted with dichloromethane $(3 \times 20 \mathrm{~mL})$ and solvent was removed from the combined extracts. The crude product was crystallized from toluene to give 23 (0.1 g, 75\%). Mp 118-119 ${ }^{\circ} \mathrm{C} .{ }^{1} \mathrm{H}$ NMR $\left(\mathrm{CDCl}_{3}\right) \delta 1.72(\mathrm{~s}, 6 \mathrm{H}), 2.18-2.27(\mathrm{~m}, 4 \mathrm{H}), 3.33(\mathrm{t}, J=6.45 \mathrm{~Hz}, 4 \mathrm{H}), 5.19(\mathrm{t}, J=2.7$ $\mathrm{Hz}, 2 \mathrm{H}), 7.70(\mathrm{~d}, J=6.6 \mathrm{~Hz}, 2 \mathrm{H}), 8.01(\mathrm{~d}, J=6.6 \mathrm{~Hz}, 2 \mathrm{H}) ;{ }^{13} \mathrm{C} \mathrm{NMR}\left(\mathrm{CDCl}_{3}\right) \delta 20.5,31.6,31.6$, 128.4, 129.2, 141.4, 156.7, 169.5, 211.1. FT-IR (KBr) $v_{\max } / \mathrm{cm}^{-1}: 2933,1742$.

trans-8,9-Diacetoxy-6,7,8,9,10,11-hexahydrocycloocta[1,2-b]pyrido[2,3-e]pyrazine 24

A mixture of the dione $22(0.2 \mathrm{~g}, 0.625 \mathrm{mmol})$ and 2,3-diaminopyridine $(0.09 \mathrm{~g}, 0.64 \mathrm{mmol})$ was heated at reflux in $\mathrm{AcOH}(10 \mathrm{~mL})$ for $3 \mathrm{~h}$. Water $(c a .10 \mathrm{~mL})$ was added and the resulting mixture extracted with dichloromethane $(3 \times 20 \mathrm{~mL})$ and solvent was removed from the combine extracts. The crude product was crystallized from ethanol/water to give $24(0.1 \mathrm{~g}, 75 \%)$. MP 134- $135{ }^{\circ} \mathrm{C} .{ }^{1} \mathrm{H}$ NMR $\left(\mathrm{CDCl}_{3}\right) \delta 1.71(\mathrm{~s}, 3 \mathrm{H}), 1.73(\mathrm{~s}, 3 \mathrm{H}), 2.1-2.4(\mathrm{~m}, 4 \mathrm{H}), 3.4(\mathrm{q}, J=6.3,4 \mathrm{H})$, $5.24(\mathrm{~s}, 2 \mathrm{H}), 7.69(\mathrm{~d}, J=4.2 \mathrm{~Hz}, 1 \mathrm{H}), 8.4(\mathrm{~d}, J=6 \mathrm{~Hz}, 1 \mathrm{H}), 9.10(\mathrm{br}, \mathrm{s}, 1 \mathrm{H}) .{ }^{13} \mathrm{C} \mathrm{NMR}\left(\mathrm{CDCl}_{3}\right) \delta$ 20.6, 20.6, 30.9, 31.3, 31.5, 31.6, 70.9, 71.1, 124.6, 133.8, 137.4, 153.0, 158.0, 159.7, 160.1, 169.

5, 169.6. FT-IR (KBr) $v_{\max } / \mathrm{cm}^{-1}: 1742,1235$. MS (EI, $70 \mathrm{ev)}: \mathrm{m} / z(\%) 329\left(\mathrm{M}^{+}, 36\right), 287$ (41), 209 (100). Found: $\mathrm{M}^{+} ; 329.1376, \mathrm{C}_{17} \mathrm{H}_{19} \mathrm{~N}_{3} \mathrm{O}_{4}$ requires $\mathrm{M}^{+} ; 329.1376$.

\section{trans-8,9-Diacetoxy-2,3-dicyano-5,6,7,8,9,10-hexahydrocycloocta[1,2-b]pyrazine 25}

A mixture of the dione $22(0.2 \mathrm{~g}, 0.625 \mathrm{mmol})$ and 1,2-diaminomaleonitrile $(0.09 \mathrm{~g}, 0.64 \mathrm{mmol})$ was heated at reflux in AcOH $(10 \mathrm{~mL})$ for $3 \mathrm{~h}$. Water $(c a .10 \mathrm{~mL})$ was added to the mixture and it was then extracted with dichloromethane $(3 \times 20 \mathrm{~mL})$ and solvent was removed from the combine extracts. The crude product crystallized from ethanol/water to give $25(0.1 \mathrm{~g}, 75 \%)$. Mp 114-116 ${ }^{\circ} \mathrm{C} .{ }^{1} \mathrm{H}$ NMR $\left(\mathrm{CDCl}_{3}\right) \delta 1.88(\mathrm{~s}, 6 \mathrm{H}), 2.1-2.3(\mathrm{~m}, 4 \mathrm{H}), 3.25(\mathrm{t}, J=6.3 \mathrm{~Hz}, 4 \mathrm{H}), 5.30(\mathrm{t}$, $J=2.1 \mathrm{~Hz}, 2 \mathrm{H}) ;{ }^{13} \mathrm{C} \mathrm{NMR}\left(\mathrm{CDCl}_{3}\right) \delta 20.6,31.0,31.2,70.4,113.0,130.6,161.7,169.0$. FT-IR $(\mathrm{KBr}) v_{\max } / \mathrm{cm}^{-1}: 2933,2241,1742$. MS (EI, $\left.70 \mathrm{ev}\right): \mathrm{m} / \mathrm{z}(\%) 328\left(\mathrm{M}^{+}, 5\right), 286(78), 244$ (100). Found: $\mathrm{M}^{+} ; 328.1171, \mathrm{C}_{16} \mathrm{H}_{16} \mathrm{~N}_{4} \mathrm{O}_{4}$ requires $\mathrm{M}^{+} ; 328.1172$.

\section{Supplementary Information Available}

The cif for the crystallographic structure determination of compound $\mathbf{1 6}$ is available as supplementary information. Additionally, the X-ray data has been deposited at the Cambridge Crystallographic Data Centre with the deposition number 637710. 


\section{Acknowledgements}

The authors are grateful to the University of Urmia for financial support for this work.

\section{References}

1. Lavoisier-Gallo, T.; Charonnet, E.; Rodriguez, J. J. Org. Chem. 1998, 63, 900.

2. Lavoisier-Gallo, T.; Charonnet, E.; Pons, J.-M.; Rajzman, M.; Faure, R.; Rodriguez, J. Chem. Eur. J. 2001, 7, 1056.

3. Chung, W.-S.; Liu, J.-H. Chem. Commun. 1997, 205.

4. Moriconi, E. J.; Misner, R. E.; Brady, T. E. J. Org. Chem. 1969, 34, 1651.

5. Haddadin, M. J.; Zahr, G. E.; Rawdah, T. N.; Chelhot, N. C.; Issidorides, C. H. Tetrahedron 1974, 30, 659 .

6. Haddadin, M. J.; Alkaysi, H. N.; Saheb, S. E. Tetrahedron 1970, 26, 1115.

7. Mufarrij, N. A.; Haddadin, M. J.; Issidorides, S. H.; McFarland, J. W.; Johnson, J. D. J. Chem. Soc., Perkin Trans. 1 1972, 965.

8. McElvain, S. M.; Stammer, C. H. J. Am. Chem. Soc. 1953, 75, 2153.

9. Cho, C. S.; Ren, W. X.; S. C. Shium, S. C. Tetrahedron Lett. 2007, 48, 4665.

10. Houminer, Y.; Williams, D. L. J. Heterocycl. Chem. 1985, $22,373$.

11. Yates, P.; Lewars, E. G.; P. H. McCabe, P. H. Can. J. Chem. 1972, 50, 1548.

12. Baskaran, S.; Das, J. Chandrasekaran, S. J. Org. Chem. 1989, 54, 5182.

13. Helliwell, M.; Alamdari, M. H; Baradarani, M. M.; Joule, J. A. Acta Crystallogr., Sect. E, Cryst. Struct. Commun. 2007, E63, o3182. 